\title{
Desain Modul Pembelajaran Mandiri Tentang Gerak Parabola Pada Bidang Datar Dengan Memperhitungkan Gesekan Udara
}

\author{
Matius Umbu Laga ${ }^{1}$, Debora Natalia Sudjito ${ }^{*}, 1,2$, Diane Noviandini ${ }^{1,2}$ \\ ${ }^{1}$ Program Studi Pendidikan Fisika, Fakultas Sains dan Matematika, Universitas Kristen Satya Wacana \\ ${ }^{2}$ Pusat Studi Sains, Teknologi, dan Matematika (e-SisTem), Fakultas Sains dan Matematika, Universitas \\ Kristen Satya Wacana \\ *email korespondensi: debora.natalia@staff.uksw.edu
}

Received : 8 Januari 2019 ; Revised : 31 Maret 2019; Accepted : 9 Juli 2019; Published: 28 Agustus 2019

\begin{abstract}
ABSTRAK
Padatnya materi fisika dan terbatasnya waktu pembelajaran membuat materi yang diajarkan tidak dapat dibahas secara mendalam khususya gerak parabola. Penelitian ini membuat desain modul pembelajaran mandiri gerak parabola pada bidang datar yang dipengaruhi hambatan udara menggunakan simulasi PhET. Tujuan penelitian ini adalah membuat desain modul pembelajaran mandiri gerak parabola pada bidang datar yang dipengaruhi hambatan udara dan mengukur efektivitas modul pembelajaran mandiri gerak parabola pada bidang datar yang dipengaruhi hambatan udara. Modul yang dibuat terdiri atas dua bagian utama, yaitu penurunan persamaan besaran-besaran fisis gerak parabola secara matematis dan menyelidiki pengaruh perubahan besaran fisis pada gerak parabola menggunakan simulasi PhET "Projectile Motion" dan Microsoft Excel. Metode penelitian yang digunakan adalah ADDIE (Analysis, Design, Development, Implementation, Evaluate). Sampel penelitian ini terdiri dari tiga orang mahasiswa pendidikan fisika tingkat dua. Berdasarkan tabel rekapitulasi lembar observasi, diperoleh persentase keberhasilan $100 \%$ dan dari tabel rekapitulasi lembar kuesioner diperoleh respon positif mahasiswa terhadap modul pembelajaran mandiri gerak parabola pada bidang datar yang dipengaruhi hambatan udara sebesar $87 \%$. Hal ini menunjukkan penggunaan modul pembelajaran mandiri yang dibuat efektif dapat membantu mahasiswa dalam menurunkan persamaan-persamaan gerak parabola pada bidang datar yang dipengaruhi hambatan udara, melakukan praktikum secara mandiri menggunakan simulasi PhET, dan Microsoft Excel serta dapat memahami materi yang dipelajari.
\end{abstract}

Kata-kata kunci: bidang datar; gerak parabola; gesekan udara; modul pembelajaran

\section{PENDAHULUAN}

Pembelajaran fisika tentang gerak parabola di kelas selama ini cenderung menggunakan pendekatan ideal dimana hambatan udara diabaikan, hal ini dilakukan agar mahasiswa lebih mudah dalam memahami materi gerak parabola. Namun, pada kenyataannya hampir semua gerak di bumi dipengaruhi oleh hambatan udara termasuk dalam hal ini adalah gerak parabola juga dipengaruhi oleh hambatan udara. Terdapat dua jenis hambatan udara dalam gerak parabola, yaitu hambatan linier dan hambatan kuadratik (Owen \& Ryu, 2005; Pramitasari, 2013; Symon, 1971). Jenis hambatan pada gerak parabola ditentukan oleh bilangan Reynolds (Re) yang memiliki persamaan:

$$
\operatorname{Re}=\frac{\rho D v}{\eta}
$$

dimana $\rho$ adalah massa jenis udara, $D$ adalah diameter benda, $v$ adalah kecepatan benda dan $\eta$ adalah viskositas udara. Jika nilai $\operatorname{Re}<10^{5}$, maka hambatannya linier dan besar hambatan udara $(f)$ dapat ditulis

$$
f=-b \cdot \vec{v}
$$

dimana nilai $b=6 \pi \eta r$, dengan $r$ adalah jari-jari benda ; jika Re $>10^{5}$, hambatannya kuadratik dimana hambatan udara $(f)$ dapat ditulis

$$
f=-b \cdot \vec{v}^{2}
$$


dimana nilai $b=0.5 \rho A C$ dengan $A$ adalah luas permukaan benda dan $C$ adalah koefisien hambatan udara (Henelsmith, 2016; Pramitasari, 2013; Rocca \& Riggi, 2009; Symon, 1971).

Pada penelitian ini kasus yang diangkat adalah gerak parabola pada bidang datar yang dipengaruhi hambatan udara yang linier karena dapat diselesaikan secara analitik. Materi gerak parabola yang dipengaruhi hambatan udara perlu dipelajari secara mendalam, sementara materi yang harus disampaikan padat dan waktu tatap muka terbatas, sehingga penugasan mandiri dapat menjadi solusi. Sejauh ini buku atau modul yang membahas gerak parabola pada bidang datar yang dipengaruhi hambatan udara sangat minim. Guna mendukung proses pembelajaran mandiri, diperlukan media pembelajaran yang cukup fleksibel, dalam hal ini berbentuk modul pembelajaran mandiri yang dikombinasikan dengan simulasi PhET.

Modul merupakan alat atau sarana pembelajaran yang berisi materi, metode, batasan-batasan, dan cara mengevaluasi yang dirancang secara sistematis dan menarik untuk mencapai kompetensi yang diharapkan sesuai dengan tingkat kompleksitasnya (Karanggulimu dkk., 2017). Penelitian ini merupakan bagian dari penelitian tentang modul gerak parabola untuk pembelajaran mandiri mahasiswa. Modul yang dibuat pada penelitian ini adalah modul pembelajaran mandiri tentang gerak parabola pada bidang datar yang dipengaruhi hambatan udara.

Dari beberapa penelitian pembuatan modul pembelajaran mandiri yang pernah dilakukan didapatkan bahwa modul praktikum mandiri menggunakan simulasi PhET efektif dalam membantu siswa untuk memahami konsep fisika, misalnya penelitian tentang Desain Modul Praktikum Mandiri Pembiasan Cahaya Menggunakan Simulasi PhET Bleding Light dapat membantu mahasiswa melakukan percobaan secara mandiri (Dinavalentine dkk., 2016). Diagram Venn Untuk Analisa Level Kognitif Mahasiswa Berdasakan Taksonomi Bloom Pada Pengembangan Modul Praktikum Mandiri Tentang Pembisan Cahaya dapat membantu mahasiswa mencapai tingkat kongnitif yang lebih tinggi (Astuti dkk., 2018); Desain Pembelajaran Dengan Menggunakan Media Simulasi PhET Pada Materi Medan Listrik dapat membantu siswa dalam memahami materi dan memotivasi siswa dalam belajar (Pujiyono dkk., 2016). Modul Pembelajaran Mandiri Tentang Gerak Parabola Pada Bidang Datar Tanpa Gesekan Udara dapat membantu mahasiswa melakukan praktikum mandiri dan memudahkan mahasiswa dalam memahami materi (Karanggulimu, L dkk., 2017). Tujuan penelitian ini adalah membuat desain modul pembelajaran mandiri tentang gerak parabola pada bidang datar yang dipengaruhi hambatan udara dan menyelidiki efektivitas desain modul yang dibuat. Manfaat dari penelitian ini adalah memperkaya modul pembelajaran fisika (mekanika) untuk mahasiswa dan membantu mahasiswa untuk mempelajari materi gerak parabola pada bidang datar yang dipengaruhi hambatan udara, melalui pembelajaran mandiri yang bisa dilakukan di luar jam tatap muka sehingga pembelajaran gerak parabola dapat dipelajari secara mendalam. Besaran-besaran fisis yang akan diturunkan dalam modul pembelajaran mandiri gerak parabola pada bidang datar yang dipengaruhi hambatan udara meliputi: percepatan $\vec{a}$; kecepatan $\vec{v}$; posisi $\vec{r}$; waktu benda untuk mencapai titik tertinggi $t$; dan waktu benda untuk mencapai titik terjauh $t$. Besaran-besaran fisis yang diselidiki pengaruhnya dalam gerak parabola yang dipengaruhi hambatan adalah besaran-besaran yang tersedia dalam simulasi PhET meliputi massa $(m)$, kecepatan awal $\left(v_{0}\right)$, sudut elevasi $(\alpha)$, koefisien hambatan udara $(\eta)$, dan diameter benda $(D)$.

\section{EKSPERIMEN}

\section{Instrumen dan Prosedur Kerja}

Penelitian ini merupakan penelitian pengembangan menggunakan model ADDIE. Model ADDIE (Analysis, Design, Develop, Implement, Evaluate) adalah salah satu model desain pembelajaran yang sifatnya lebih generik. Salah satu fungsi ADDIE yaitu menjadi pedoman dalam membangun perangkat dan infrastuktur program pelatihan yang efektif, dinamis, dan mendukung kinerja pelatihan itu sendiri. Model ini menggunakan 5 tahap pengembangan yaitu (Kartika Sari, 2017; Maribe Branch, 2009):

\section{Analysis (Analisis)}

Pembelajaran tentang gerak parabola selama ini cenderung mengabaikan hambatan udara, padahal hampir semua gerak dipengaruhi oleh hambatan udara. Hal ini disebabkan terbatasnya waktu pembelajaran di dalam kelas dan padatnya materi yang harus diajarkan mengakibatkan pembahasan materi gerak parabola hanya sebatas pada gerak parabola tanpa hambatan udara. Untuk mempelajari gerak parabola secara mendalam yang mencakup gerak parabola yang dipengaruhi hambatan udara, diperlukan waktu yang lebih lama, penugasan mandiri dapat menjadi solusinya. Untuk mendukung proses penugasan mandiri, diperlukan media pembelajaran yang cukup fleksibel, dalam hal ini berbentuk modul pembelajaran mandiri yang dikombinasikan dengan simulasi PhET. 


\section{Design (Desain)}

Untuk mengatasi permasalahan pada tahap analisis maka perlu dibuat suatu modul pembelajaran mandiri. Modul pembelajaran mandiri ini dibuat untuk membantu dan menuntun mahasiswa agar mahasiswa dapat memahami materi gerak parabola pada bidang datar yang dipengaruhi hambatan udara secara mandiri. Hambatan udara yang digunakan dalam modul adalah hambatan linier karena dapat diselesaikan secara analitik. Tujuan dari pembuatan modul agar mahasiswa dapat menurunkan persamaanpersamaan gerak parabola di bidang datar yang dipengaruhi hambatan udara dan menyelidiki pengaruh besaran fisis terhadap gerak parabola baik secara visual dan perhitungan. Untuk itu modul yang dibuat terdiri dari dua bagian utama yaitu penurunan persamaan-persamaan gerak parabola (posisi, kecepatan, percepatan, waktu untuk mencapai titik tertinggi, dan waktu untuk mencapai jarak terjauh) secara matematis dan menyelidiki pengaruh perubahan besaran-besaran fisis terhadap lintasan gerak parabola secara visual menggunakan simulasi PhET dan secara perhitungan menggunakan Microsoft Excel. Dalam simulasi PhET, besaran-besaran fisis yang dapat diubah-ubah adalah massa benda $(m)$, diameter benda $(D)$, kecepatan awal $\left(v_{0}\right)$, sudut elevasi $(\alpha)$, dan koefisien hambatan udara $(\eta)$.

\section{Development (Pengembangan)}

Pada bagian development ini merupakan realisasi dari desain modul pembelajaran mandiri. Modul yang dibuat adalah kelanjutan dari modul sebelumnya yang pernah dibuat oleh Liyensi Karanggulimu (Karanggulimu, L dkk., 2017) yang membahas gerak parabola pada bidang datar tanpa hambatan udara. Pada modul pembelajaran mandiri ini membahas gerak parabola pada bidang datar yang dipengaruhi hambatan udara. Pada bagian pertama modul, diberikan informasi tentang jenis-jenis hambatan udara baik hambatan linier maupun hambatan kuadratik. Selanjutnya, mahasiswa ditugaskan menurunkan persamaan-persamaan gerak parabola dengan hambatan udara linier dengan bantuan langkah-langkah penurunan persamaan. Pertama mahasiswa ditugaskan mencari persamaan percepatan dari persamaan Hukum Newton II, selanjutnya untuk mencari persamaan kecepatan dengan mengintegralkan persamaan percepatan, kemudian persamaan posisi diperoleh dengan mengintegralkan persamaan kecepatan, di akhir bagian pertama modul mahasiswa mencari persamaan waktu untuk mencapai titik tertinggi dan waktu untuk mencapai jarak terjauh. Modul bagian kedua disusun agar mahasiswa dapat menyelidiki pengaruh perubahan massa benda, diameter benda, kecepatan benda, sudut elevasi, dan koefisien hambatan udara terhadap lintasan gerak parabola secara visual, menggunakan simulasi PhET "Projectile Motion" kemudian menghitung pengaruh variabel-variabel tersebut terhadap jarak maksimum, ketinggian maksimum, waktu mencapai titik tertinggi dan waktu untuk mencapai jarak maksimum menggunakan Microsoft Excel. Di dalam modul bagian kedua ini terdapat pertanyaan-pertanyaan yang bisa menggiring mahasiswa untuk memahami konsep dan menerapkan rumus yang telah diperoleh dari modul bagian pertama untuk mengetahui pengaruh variabelvariabel tersebut di atas terhadap ketinggian maksimum, jarak terjauh, waktu untuk mencapai tinggi maksimum, waktu untuk mencapai titik terjauh pada gerak parabola bidang datar, dan kesimpulan akhir yang benar. Setelah modul selesai dibuat, dilakukan uji coba modul terhadap dua mahasiswa tingkat tiga mengenai isi modul dan langkah-langkah yang terdapat dalam modul, masukan yang diperoleh akan digunakan untuk memperbaiki modul sebelum diimplementasikan. Pada bagian development selain pembuatan modul juga dibuat instrumen penelitian berupa lembar observasi dan lembar kuesioner. Opsi dalam lembar observasi berupa jawaban "YA" dan "TIDAK" terhadap keberhasilan langkah-langkah pembelajaran, sedangkan opsi dalam lembar kuesioner berupa skala dari 1-4 (1 = sangat tidak setuju, 2 = tidak setuju, 3 = setuju, 4 = sangat setuju) terhadap sikap mahasiswa pada penggunaan modul pembelajaran mandiri.

\section{Implementation (Implementasi)}

Responden penelitian ini adalah tiga mahasiswa Pendidikan Fisika tingkat dua. Instrumen penelitian yang digunakan adalah modul praktikum, lembar observasi, dan lembar kuesioner. Modul pembelajaran diberikan ke mahasiswa untuk dikerjakan. Selama mahasiswa mengerjakan modul, observer mengisi lembar observasi dan mendokumentasikan jalannya pembelajaran. Lembar observasi digunakan untuk merekam berlangsungnya kegiatan pembelajaran mandiri mahasiswa. Setelah mahasiswa selesai mengerjakan modul, kuesioner diberikan kepada mahasiwa. Lembar kuesioner untuk mengetahui tanggapan mahasiswa terhadap modul pembelajaran mandiri gerak parabola pada bidang datar yang dipengaruhi hambatan udara.

\section{Evaluation (Evaluasi)}

Pada tahap evaluasi semua data yang diperoleh dari lembaran observasi dan lembaran kuesioner dianalisa secara deskriptif kualitatif untuk mengetahui apakah modul pembelajaran mandiri tentang gerak 
parabola ini dapat dikatakan efektif bagi mahasiswa utuk mempelajari materi. Melalui lembar observasi, kita dapat mengukur ketercapaian tujuan pengembangan modul, mengukur apa yang telah mampu dicapai mahasiswa, dan melihat kembali dampak dari pembelajaran mandiri menggunakan modul. Melalui lembar kuesioner, kita dapat mengukur respon positif dari sampel terhadap modul pembelajaran mandiri gerak parabola pada bidang datar yang dipengaruhi hambatan udara. Modul ini dapat dikatakan efektif apabila (1) semua responden dapat mengikuti minimal $70 \%$ dari semua langkah di dalam modul pembelajaran mandiri dengan benar berdasarkan lembar observasi dan modul, (2) semua responden memberikan umpan balik positif terhadap minimal 70\% pertanyaan di kuesioner (Dinavalentine dkk., 2016; Karanggulimu, L dkk., 2017).

\section{HASIL DAN DISKUSI}

Modul gerak parabola pada bidang datar yang dipengaruhi hambatan udara ini terdiri atas dua bagian utama, yaitu penurunan persamaan besaran-besaran fisis gerak parabola secara matematis dan menyelidiki pengaruh perubahan besaran fisis pada gerak parabola menggunakan simulasi PhET "Projectile Motion" dan Microsoft Excel. Modul ini dibuat untuk level mahasiswa S1. Ada tiga mahasiswa Pendidikan Fisika tingkat pertama yang menjadi responden dalam penelitian ini. Pada modul bagian pertama ini terdapat lima tujuan yaitu : mahasiswa dapat: (1) menemukan persamaan percepatan benda $\left(a_{x}, a_{y}\right)$, (2) menemukan persamaan kecepatan benda $\left(v_{x}, v_{y}\right),(3)$ menemukan persamaan posisi $(x, y),(4)$ menemukan persamaan waktu saat benda mencapai titik tertinggi, dan (5) menemukan persamaan waktu saat benda mencapai titik terjauh pada gerak parabola bidang datar yang dipengaruhi hambatan udara. Sedangkan modul bagian kedua memiliki tujuan: mahasiswa menyelidiki pengaruh $(1)$ massa benda $(m),(2)$ diameter benda $(D),(3)$ kecepatan awal benda $\left(v_{0}\right)$, (4)sudut elevasi $(\alpha)$, dan (5) koefisien hambatan udara $(\eta)$; terhadap lintasan gerak parabola, jarak maksimum, ketinggian maksimum, waktu untuk mencapai titik tertinggi, dan waktu untuk mencapai jarak maksimum mengggunakan simulasi PhET "Projectile Motion" dan Microsoft Excel. Sebelum penurunan persamaan besaran-besaran fisis gerak parabola pada bidang datar yang dipengaruhi hambatan udara secara matematis, diberikan suatu pengantar berupa sketsa lintasan gerak parabola pada bidang datar yang dipengaruhi hambatan udara pada koordinat Cartesius $(x, y)$. Kemudian dijelaskan ada dua jenis hambatan udara yang ditentukan oleh Bilangan Reynolds $(R e)$, yaitu hambatan linier dan hambatan kuadratik. Jika nilai $R e<10^{5}$, besar hambatannya linier dihitung mengunakan persamaan (2), sedangkan jika nilai $\operatorname{Re}>10^{5}$, besar hambatannya kuadratik dihitung menggunakan persamaan (3).

Pada penelitian ini kasus yang diangkat adalah gerak parabola pada bidang datar yang dipengaruhi hambatan udara linier dimana nilai $b=6 \pi \eta r$ karena dapat diturunkan secara matematis, sedangkan hambatan udara kuadratik sangat sulit diturunkan secara matematis maka untuk mengerjakannya digunakan pendekatan secara numerik.

\section{Pada modul bagian pertama mahasiswa ditugaskan menurunkan:}

1. Persamaan percepatan $\left(a_{x}, a_{y}\right)$ pada gerak parabola di bidang datar yang dipengaruhi hambatan udara.

Pada bagian ini mahasiswa ditugaskan untuk menemukan persamaan percepatan pada gerak parabola di bidang datar yang dipengaruhi hambatan udara secara matematis menggunakan persamaan Hukum Newton II. Pada gerak parabola yang dipengaruhi hambatan udara gaya-gaya yang bekerja adalah gaya berat $(W)$ dan gaya hambatan udara $\left(f_{\text {ges }}\right)$. Dengan mempertimbangkan gaya-gaya yang bekerja, mahasiswa digiring untuk menggunakan persamaan Hukum Newton II, sampai diperoleh persamaan umum vektor percepatan benda $(\vec{a})$ pada gerak parabola yang dipengaruhi hambatan udara berikut:

$$
\vec{a}=\vec{g}-\frac{b}{m} \vec{v}
$$

Selanjutnya mahasiswa diminta untuk mencari persamaan percepatan pada sumbu $\mathrm{x}\left(a_{x}\right)$. Pada sumbu $x$, percepatan gravitasi bernilai nol $\left(g_{x}=0\right)$, sedangkan komponen kecepatan pada sumbu $\mathrm{x}$ tidak bernilai nol $\left(v_{x} \neq 0\right)$, sehingga diperoleh persamaan percepatan benda pada gerak parabola yang dipengaruhi hambatan udara pada sumbu $x$ adalah

$$
a_{x}=-\frac{b}{m} v_{x}
$$

Kemudian pada sumbu $y$, percepatan gravitasi tidak bernilai nol $\left(g_{y} \neq 0\right)$, demikian juga komponen kecepatan pada sumbu y tidak bernilai nol $\left(v_{y} \neq 0\right)$. Karena arah vektor percepatan gravitasi pada sumbu y adalah ke bawah sehingga diperoleh $g_{y}=-g$. Dengan mensubtitusikan besaran-besaran 
yang diketahui pada sumbu y ke dalam persamaan umum percepatan, maka diperoleh persamaan percepatan benda pada sumbu y adalah

$$
a_{y}=-g-\frac{b}{m} v_{y}
$$

Di akhir bagian ini, mahasiswa ditugaskan menuliskan notasi vektor percepatan dari persamaan komponen vektor percepatan, yaitu:

$$
\vec{a}=-\frac{b}{m} v_{x} \hat{\imath}-\left(g+\frac{b}{m} v_{y}\right) \hat{\jmath}
$$

Pada bagian ini, berdasarkan data dari Tabel 1 poin 3A dan Tabel 2 poin 1 serta modul, semua mahasiswa tidak mengalami kesulitan dan mampu menemukan persamaan percepatan benda pada gerak parabola bidang datar yang dipengaruhi hambatan udara. Hal ini berarti langkah-langkah penggiring pada modul dapat dipahami oleh mahasiswa dan efektif digunakan untuk menuntun mahasiswa untuk menemukan persamaan percepatan pada gerak parabola di bidang datar yang dipengaruhi hambatan udara secara matematis (Dinavalentine dkk., 2016; Karanggulimu, L dkk., 2017).

2. Persamaan kecepatan $\left(v_{x}, v_{y}\right)$ pada gerak parabola pada bidang datar yang dipengaruhi hambatan udara

Pada bagian ini mahasiswa ditugaskan untuk menemukan persamaan kecepatan pada gerak parabola di bidang datar yang dipengaruhi hambatan udara secara matematis menggunakan persamaan percepatan. Mahasiswa diminta untuk menemukan persamaan kecepatan pada arah sumbu $x$ dan arah sumbu $y$, menggunakan persamaan percepatan pada arah sumbu $x$ dan arah sumbu $y$ dengan mengingat bahwa percepatan merupakan turunan pertama dari kecepatan terhadap waktu $(a=d v / d t)$ (Halliday dkk., 2010). Pada arah sumbu $x$, digunakan persamaan percepatan $a_{x}$. Dengan mengintegralkan persamaan percepatan $a_{x}$ diperoleh persamaan kecepatan arah sumbu x, (Tan \& Edwards, 2011) :

$$
v_{x}=v_{0} \cos \alpha e^{-\frac{b}{m} t}
$$

Berdasarkan data pada lembar observasi dan kuesioner, ketiga mahasiswa dapat menemukan persamaan kecepatan secara mandiri. Hal ini berarti semua mahasiswa tidak mengalami kesulitan dalam menurunkan persamaan kecepatan $v_{x}$. Selanjutnya pada arah sumbu y, digunakan persamaan percepatan arah sumbu y. Sebelum melakukan integral, mahasiswa diminta untuk melakukan pemodelan persamaan percepatan pada sumbu y, yaitu mulai dari:

sampai menjadi bentuk persamaan:

$$
a_{y}=-g-\frac{b}{m} v_{y}
$$

$$
\frac{d v_{y}}{d t}=-g\left(1+\frac{b}{m g} v_{y}\right)
$$

Setelah pemodelan dilakukan mahasiswa diminta untuk mengintegralkan persamaan $a_{y}$, sehingga diperoleh persamaan kecepatan arah sumbu y (Tan \& Edwards, 2011) :

$$
v_{y}=\left(\frac{m g}{b}+v_{0} \sin \alpha\right) e^{-\frac{b}{m} t}-\frac{m g}{b}
$$

Dalam penurunan persamaan percepatan $a_{y}$ sehingga diperoleh persamaan kecepatan $v_{y}$, satu dari tiga responden mengalami kesulitan dalam melakukan pemodelan persamaan. la sebenarnya sudah menemukan persamaan $\frac{d v}{d t}$ dengan benar, namun ia kesulitan mengubah persamaan (9) menjadi persamaan (10). Responden yang mengalami kesulitan dibantu oleh observer dalam mengolah informasi yang terdapat pada modul sehingga responden dapat melakukan pemodelan persamaan. Selanjutnya, responden dapat menurunkan persamaan secara mandiri. Saat menggunakan modul praktikum mandiri, seharusnya responden tidak boleh bertanya pada observer. Namun kenyataannya, terdapat responden yang bertanya pada observer, yaitu pada bagian pemodelan persamaan. Responden kurang mengerti makna dari variasi letak tanda plus dan minus pada persamaan. Tanda plus dan minus dalam persamaan matematis dapat ditulis dalam berbagai variasi, sejauh prinsip/hukum matematis tidak dilanggar dan persamaan tersebut memiliki makna yang sama. Dengan demikian, untuk mengantisipasi kesulitan serupa, perlu ditambahkan beberapa informasi atau kalimat penggiring sehingga jika modul ini digunakan untuk responden yang lain, responden tersebut tidak akan mengalami kesulitan dalam penurunan 
persamaan kecepatan pada sumbu y dengan mengerjakan secara mandiri. Pada bagian akhir dari kegiatan ini mahasiswa ditugaskan menuliskan notasi vektor kecepatan dari persamaan-persamaan komponen vektor yang telah diperoleh yaitu :

$$
\vec{v}=\left[v_{0} \cos \alpha e^{-\frac{b}{m} t}\right] \hat{\imath}+\left[\left(\frac{m g}{b}+v_{0} \sin \alpha\right) e^{-\frac{b}{m} t}-\frac{m g}{b}\right] \hat{\jmath}
$$

Berdasarkan data dari Tabel 1 poin 3B dan Tabel 2 poin 1 serta modul, satu dari tiga responden mengalami kesulitan namun pada langkah-langkah selanjutnya semua responden tidak mengalami kesulitan dan mampu menemukan persamaan kecepatan benda pada gerak parabola bidang datar yang dipengaruhi hambatan udara. Hal ini berarti langkah-langkah penggiring pada modul dapat dipahami oleh mahasiswa dan efektif digunakan dalam menuntun mahasiswa untuk menemukan persamaan kecepatan pada gerak parabola bidang datar yang dipengaruhi hambatan udara secara matematis (Dinavalentine dkk., 2016; Karanggulimu, L dkk., 2017).

3. Persamaan posisi $(x, y)$ gerak parabola pada bidang datar yang dipengaruhi hambatan udara.

Pada kegiatan ini, mahasiswa ditugaskan untuk menemukan persamaan umum posisi $(x, y)$, dengan memanfaatkan persamaan kecepatan dimana kecepatan merupakan turunan pertama dari posisi terhadap waktu ( $v=d r / d t$ )(Halliday dkk., 2010). Untuk mencari persamaan umum posisi benda yang bergerak pada komponen $x$ dalam gerak parabola yang dipengaruhi hambatan udara, mahasiswa diminta untuk mengintegralkan persamaan kecepatan pada sumbu $x$ sehingga diperoleh persamaan posisi pada sumbu x yaitu (Morales, 2005; Rocca \& Riggi, 2009; Symon, 1971; Tan \& Edwards, 2011):

$$
x=\frac{m}{b} v_{0} \cos \alpha\left[1-e^{-\frac{b}{m} t}\right]
$$

Selanjutnya mahasiswa mencari persamaan posisi pada sumbu y. Untuk menemukan persamaan posisi pada sumbu y, digunakan persamaan kecepatan pada sumbu y dan mengintegralkannya sehingga diperoleh persamaan yaitu (Morales, 2005; Rocca \& Riggi, 2009; Symon, 1971; Tan \& Edwards, 2011) :

$$
y=\left(\frac{m^{2} g}{b^{2}}+\frac{m}{b} v_{0} \sin \alpha\right)\left(1-e^{-\frac{b}{m} t}\right)-\left(\frac{m g}{b} t\right)
$$

Pada bagian akhir dari kegiatan ini mahasiswa ditugaskan menuliskan persamaan posisi dalam notasi vektor berikut:

$$
\vec{r}=\left[v_{0} \cos \alpha \frac{m}{b}\left(1-e^{-\frac{b}{m} t}\right)\right] \hat{\imath}+\left[\left(\frac{m^{2} g}{b^{2}}+\frac{m}{b} v_{0} \sin \alpha\right)\left(1-e^{-\frac{b}{m} t}\right)-\left(\frac{m g}{b} t\right)\right] \widehat{\jmath}
$$

Pada kegiatan ini semua responden tidak mengalami kesulitan dalam mengintegralkan persamaan kecepatan hingga diperoleh persamaan umum posisi benda yang bergerak pada komponen $\mathrm{x}$ dan y. Berdasarkan data dari Tabel 1 poin 3C dan Tabel 2 poin 1 serta modul, mahasiswa dapat mengikuti langkah-langkah pada modul dengan baik dan benar serta informasi yang diberikan pada modul dapat membantu mahasiswa dalam penurunan persamaan. Hal ini berarti langkah-langkah penggiring pada modul dapat dipahami oleh mahasiswa dan efektif digunakan untuk menuntun mahasiswa dalam menemukan persamaan posisi pada gerak parabola bidang datar yang dipengaruhi hambatan udara secara matematis (Dinavalentine dkk., 2016; Karanggulimu, L dkk., 2017).

\section{Persamaan waktu untuk mencapai titik tertinggi $\left(t_{\text {tertinggi }}\right)$}

Pada kegiatan ini, mahasiswa ditugaskan untuk menemukan persamaan waktu benda untuk mencapai titik tertinggi. Pada saat benda mencapai titik tertinggi pada gerak parabola bidang datar yang dipengaruhi hambatan udara, komponen kecepatan pada sumbu y sama dengan nol $\left(v_{t y}=0\right)$ (Halliday dkk., 2010). Dengan memanfaatkan persamaan kecepatan pada sumbu y dan menurunkannya sampai diperoleh persamaan waktu di titik tertinggi (Tan \& Edwards, 2011):

$$
t_{\text {terting } i}=\frac{m}{b} \ln \left(1+\frac{b v_{0} \sin \alpha}{m g}\right)
$$

Pada kegiatan ini semua responden tidak mengalami kesulitan dan dapat menurunkan persamaan waktu benda untuk mencapai titik tertinggi. Berdasarkan data dari Tabel 1 poin 3D dan Tabel 2 poin 1 serta modul, responden dapat mengikuti langkah-langkah dengan baik yang terdapat dalam modul serta informasi yang terdapat pada modul sangat membantu responden dalam penurunan persamaan sampai diperoleh persamaan waktu benda mencapai titik tertinggi. Hal ini berarti langkah-langkah penggiring pada modul dapat dipahami oleh mahasiswa dan efektif digunakan dalam menuntun mahasiswa untuk menemukan persamaan waktu benda saat mencapai titik tertinggi pada gerak parabola bidang datar yang dipengaruhi hambatan udara secara matematis (Dinavalentine dkk., 2016; Karanggulimu, L dkk., 2017).

\section{Persamaan waktu untuk mencapai titik terjauh ( $\left.t_{\text {maksimum }}\right)$}


Dalam kegiatan ini mahasiswa diminta untuk menemukan persamaan waktu untuk mencapai titik terjauh. Saat benda jatuh mencapai tanah, saat itu jaraknya maksimum dan ketinggian benda pada sumbu $y$ sama dengan nol $(y=0)$ (Halliday dkk., 2010), sehingga untuk mencari waktu yang diperlukan untuk mencapai jarak maksimum, mahasiswa dapat menggunakan persamaan umum posisi pada sumbu:

$$
y=\left(\frac{m^{2} g}{b^{2}}+\frac{m}{b} v_{0} \sin \alpha\right)\left(1-e^{-\frac{b}{m} t}\right)-\left(\frac{m g}{b} t\right)=0
$$

Karena terdapat dua suku yang memiliki variabel $t$, yaitu dalam bentuk linier $\left(\frac{m g}{b} t\right)$ dan dalam bentuk eksponensial $\left(1-e^{-\frac{b}{m} t}\right)$, sehingga untuk menyelesaikan persamaan di atas, digunakan pendekatan deret MacLaurin. Berdasarkan pendekatan deret MacLaurin dari bentuk eksponensial $\left(1-e^{-\frac{b}{m} t}\right)$, tiga suku pertamanya dapat ditulis menjadi $1+\left(-\frac{b}{m} t\right)+\frac{\left(-\frac{b}{m} t\right)^{2}}{2}$ (Boas, 1976). Jadi persamaan yang diperoleh adalah :

$$
0=\left(\frac{m^{2} g}{b^{2}}+\frac{m}{b} v_{0} \sin \alpha\right)\left(1-\left(1+\left(-\frac{b}{m} t\right)+\frac{\left(-\frac{b}{m} t\right)^{2}}{2}\right)\right)-\left(\frac{m g}{b} t\right)
$$

Langkah selanjutnya mahasiswa diminta untuk menyelesaikan persamaan di atas hingga diperoleh persamaan akhir untuk mencari waktu benda mencapai jarak maksimum adalah :

$$
t_{\text {terjauh }}=\frac{v_{0} \sin \alpha}{\left(\frac{g}{2}+\frac{b v_{0} \sin \alpha}{2 m}\right)}
$$

Pada kegiatan ini, semua responden tidak mengalami kesulitan dan dapat menurunkan persamaan waktu benda mencapai titik terjauh. Responden juga dapat menemukan persamaan waktu benda mencapai titik terjauh secara mandiri. Tetapi pada bagian akhir persamaan ini semua mahasiswa masih keliru menempatkan tanda plus dan minus karena kurang teliti menyederhanakan persamaan secara matematis sehingga perlu ditambahkan beberapa informasi berupa pertanyaan penggiring, penegasan tanda plus dan minus. Berdasarkan data dari Tabel 1 poin 3E dan Tabel 2 poin 1, responden dapat mengikuti langkah-langkah yang terdapat pada modul dengan baik.

Pada bagian kedua modul ini, mahasiswa ditugaskan menyelidiki pengaruh massa benda $(m)$, diameter benda $(D)$, kecepatan awal benda $\left(v_{0}\right)$, sudut elevasi $(\alpha)$, dan koefisien hambatan udara $(\eta)$ terhadap lintasan gerak parabola, jarak maksimum, ketinggian maksimum, waktu untuk mencapai titik tertinggi, dan waktu untuk mencapai jarak maksimum menggunakan simulasi PhET "Projectile Motion" dan Microsoft Excel.

A. Menyelidiki pengaruh massa benda terhadap jarak maksimum, ketinggian maksimum, waktu mencapai titik tertinggi dan waktu untuk mencapai jarak maksimum menggunakan simulasi PhET "Projectile Motion" dan Microsoft Excel.

Pada kegiatan ini mahasiswa ditugaskan menyelidiki pengaruh massa dengan cara mengubah nilai massa dari $1 \mathrm{~kg}, 2 \mathrm{~kg}, 3 \mathrm{~kg}$ dan $4 \mathrm{~kg}$, sedangkan besaran lain dibuat tetap yaitu sudut elevasi $30^{\circ}$; percepatan gravitasi $9,8 \mathrm{~m} / \mathrm{s}^{2}$; kecepatan awal benda $15 \mathrm{~m} / \mathrm{s}$; diameter benda $0,1 \mathrm{~m}$; dan koefisien hambatan udara $0,47 \mathrm{~kg} / \mathrm{ms}$. Selama praktikum berlangsung, mahasiswa mengamati lintasan gerak benda khususnya pengaruh massa benda terhadap jarak maksimum dan ketinggian maksimum menggunakan simulasi PhET, kemudian melakukan perhitungan menggunakan Microsoft Excel dan menuliskan hasilnya pada tabel yang terdapat dalam modul. Berdasarkan simulasi PhET dan perhitungan Microsoft Excel, diperoleh kesimpulan bahwa semakin besar massa benda, semakin besar ketinggian maksimum dan waktu untuk mencapai titik tertinggi, tetapi semakin kecil jarak maksimum dan waktu untuk mencapai jarak maksimum.

B. Menyelidiki pengaruh diameter benda terhadap jarak maksimum, ketinggian maksimum, waktu mencapai titik tertinggi, dan waktu untuk mencapai jarak maksimum menggunakan simulasi PhET "Projectile Motion" dan Microsoft Excel.

Pada kegiatan ini mahasiswa ditugaskan menyelidiki pengaruh diameter benda dengan cara mengubah nilai diameter benda dari 0,$1 ; 0,2 ; 0,3$; dan $0,4 \mathrm{~m}$, besaran yang lain dibuat tetap yaitu sudut elevasi $30^{\circ}$; percepatan gravitasi $9,8 \mathrm{~m} / \mathrm{s}^{2}$; kecepatan awal benda $15 \mathrm{~m} / \mathrm{s}$; massa benda $1 \mathrm{~kg}$; dan koefisien hambatan udara $0,47 \mathrm{~kg} / \mathrm{ms}$. Selama praktikum berlangsung, mahasiswa mengamati lintasan gerak benda khususnya pengaruh diameter benda terhadap jarak maksimum dan ketinggian 
maksimum menggunakan simulasi PhET, kemudian melakukan perhitungan menggunakan Microsoft Excel dan menuliskan hasilnya pada tabel yang terdapat dalam modul. Berdasarkan simulasi PhET dan perhitungan Microsoft Excel, diperoleh bahwa semakin besar diameter benda, semakin kecil jarak maksimum, ketinggian maksimum, waktu untuk mencapai titik tertinggi, dan waktu untuk mencapai jarak maksimum.

C. Menyelidiki pengaruh kecepatan awal benda terhadap jarak maksimum, ketinggian maksimum, waktu mencapai titik tertinggi dan waktu untuk mencapai jarak maksimum menggunakan simulasi PhET "Projectile Motion" dan Microsoft Excel.

Pada kegiatan ini mahasiswa ditugaskan menyelidiki pengaruh kecepatan awal benda dengan cara mengubah nilai kecepatan awal benda dari $15,20,25$, dan $30 \mathrm{~m} / \mathrm{s}$, sedangkan besaran yang lain dibuat tetap yaitu sudut elevasi $30^{\circ}$; percepatan gravitasi $9,8 \mathrm{~m} / \mathrm{s}^{2}$; diameter benda $0,1 \mathrm{~m}$; massa benda $1 \mathrm{~kg}$; dan koefisien hambatan udara $0,47 \mathrm{~kg} / \mathrm{ms}$. Selama praktikum berlangsung, mahasiswa mengamati lintasan gerak benda khususnya pengaruh kecepatan awal benda terhadap jarak maksimum dan ketinggian maksimum menggunakan simulasi PhET, kemudian melakukan perhitungan menggunakan Microsoft Excel dan menuliskan hasilnya pada tabel yang terdapat dalam modul. Berdasarkan simulasi PhET dan perhitungan Microsoft Excel, kesimpulan yang diperoleh menyatakan bahwa semakin besar kecepatan awal benda, semakin besar jarak maksimum, ketinggian maksimum, waktu untuk mencapai titik tertinggi, dan waktu untuk mencapai jarak maksimum.

D. Menyelidiki pengaruh sudut elevasi terhadap jarak maksimum, ketinggian maksimum, waktu mencapai titik tertinggi, dan waktu untuk mencapai jarak maksimum menggunakan simulasi PhET "Projectile Motion" dan Microsoft Excel.

Pada kegiatan ini mahasiswa ditugaskan menyelidiki pengaruh sudut elevasi dengan cara mengubah nilai sudut elevasi dari $15^{\circ}, 25^{\circ}, 35^{\circ}, 45^{\circ}$. Sedangkan besaran yang lain dibuat tetap antara lain kecepatan awal benda $30 \mathrm{~m} / \mathrm{s}$; percepatan gravitasi $9,8 \mathrm{~m} / \mathrm{s}^{2}$; diameter benda $0,1 \mathrm{~m}$; massa benda $1 \mathrm{~kg}$; dan koefisien hambatan udara $0,47 \mathrm{~kg} / \mathrm{ms}$. Selama praktikum berlangsung mahasiswa mengamati lintasan gerak benda khususnya pengaruh sudut elevasi terhadap jarak maksimum dan ketinggian maksimum menggunakan simulasi PhET, kemudian melakukan perhitungan menggunakan Microsoft Excel dan menuliskan hasilnya pada tabel yang terdapat dalam modul. Berdasarkan simulasi PhET dan perhitungan Microsoft Excel, kesimpulan yang diperoleh menyatakan sudut elevasi berpengaruh terhadap jarak maksimum, ketinggian maksimum, waktu mencapai titik tertinggi, dan waktu untuk mencapai jarak maksimum. Berdasarkan pengamatan yang diperoleh lewat simulasi PhET dari sudut yang digunakan $\left(15^{\circ}-45^{\circ}\right)$, semakin besar sudutnya semakin besar ketinggian maksimum, waktu untuk mencapai titik tertinggi, jarak terjauh dan waktu untuk mencapai jarak terjauh. Sedangkan dari hasil perhitungan Microsoft Excel untuk jarak terjauhnya terdapat perbedaan dengan simulasi PhET. Dengan perhitungan Microsoft Excel diperoleh dari sudut $15^{\circ}-35^{\circ}$, semakin besar sudut jarak maksimumnya semakin besar, namun ketika menggunakan sudut 45 jarak maksimumnya kembali mengecil. Perbedaan hasil PhET dan perhitungan Microsoft Excel membingungkan mahasiswa dan menimbulkan pertanyaan. Hal ini terjadi karena pada simulasi PhET digunakan hambatan kuadratik sedangkan perhitungan Microsoft Excel menggunakan hambatan linier. Berdasarkan hasil penelitian yang dilakukan oleh D.A. Morales menyatakan bahwa sudut yang memiliki jarak maksimum pada gerak parabola yang dipengaruhi hambatan linier berkisar antara $36^{\circ}-38,4^{\circ}$ (Morales, 2005).

E. Menyelidiki pengaruh koefisien hambatan udara terhadap lintasan gerak parabola, jarak maksimum, ketinggian maksimum, waktu mencapai titik tertinggi, dan waktu untuk mencapai jarak maksimum menggunakan simulasi PhET "Projectile Motion" dan Microsoft Excel.

Pada kegiatan ini mahasiswa ditugaskan menyelidiki pengaruh koefisien hambatan udara dengan cara mengubah nilai koefisien hambatan udara dari 0,$1 ; 0,2 ; 0,3$; dan $0,4 \mathrm{~kg} / \mathrm{ms}$; sedangkan besaran yang lain dibuat tetap yaitu kecepatan awal benda $30 \mathrm{~m} / \mathrm{s}$; percepatan gravitasi $9,8 \mathrm{~m} / \mathrm{s}^{2}$; diameter benda $0,1 \mathrm{~m}$; massa benda $1 \mathrm{~kg}$; dan sudut elevasi $30^{\circ}$. Selama praktikum berlangsung mahasiswa mengamati lintasan gerak benda khususnya pengaruh koefisien hambatan udara terhadap jarak maksimum dan ketinggian maksimum menggunakan simulasi PhET, kemudian melakukan perhitungan menggunakan Microsoft Excel dan menuliskan hasilnya pada tabel yang terdapat dalam modul. Berdasarkan simulasi PhET dan perhitungan Microsoft Excel, diperoleh kesimpulan bahwa semakin besar koefisien hambatan udara, semakin kecil jarak maksimum, ketinggian maksimum, waktu untuk mencapai titik tertinggi, dan waktu untuk mencapai jarak maksimum. 
Berdasarkan data dari lembaran observasi, mahasiswa dapat melakukan praktikum secara mandiri dan mengikuti langkah-langkah dengan baik dan menjawab pertanyaan dengan benar. Hal ini menunjukkan bahwa pertanyaan penggiring yang terdapat pada modul efektif dalam membantu mahasiswa menjawab dan memahami materi gerak parabola bidang datar yang dipengaruhi hambatan udara.

\section{Lembar Observasi}

Selama responden mengerjakan modul dan melakukan praktikum secara mandiri, observer mengamati responden memberi penilaian lewat lembaran observasi. Hasil observasi dapat dilihat pada Tabel 1. Berdasarkan data observasi yang terdapat pada Tabel 1, semua sampel dapat mengikuti langkah-langkah dan menjawab pertanyaan-pertanyaan dalam modul praktikum mandiri gerak parabola pada bidang datar yang dipengaruhi hambatan udara dengan baik dan benar. Berdasarkan tabel rekapitulasi lembar observasi diperoleh persentase keberhasilan 100\%, dengan demikian modul ini dapat membantu mahasiswa untuk memahami materi dan menuntun mahasiswa melakukan praktikum dengan baik dan benar menggunakan modul praktikum mandiri gerak parabola pada bidang data yang dipengaruhi hambatan udara.

Tabel 1. Rekapitulasi Lembar Observasi

\begin{tabular}{clccc}
\hline \multirow{2}{*}{ NO } & \multicolumn{1}{c}{ Indikator } & \multicolumn{3}{c}{ Responden } \\
& & A & B & C \\
\hline 1 & Mahasiswa mengikuti langkah-langkah sesuai dengan modul. & $100 \%$ & $100 \%$ & $100 \%$ \\
2 & Mahasiswa bertanya $\leq$ 5 kali mengenai isi dan kejelasan modul. & $100 \%$ & $100 \%$ & $100 \%$ \\
3 & Dari modul pembelajaran mandiri gerak parabola pada bidang datar yang & &
\end{tabular}

Dari modul pembelajaran mandiri gerak parabola
dipengaruhi hambatan udara, mahasiswa dapat:

A. Menemukan persamaan :

- Percepatan sumbu $x\left(a_{x}\right)$

- Percepatan sumbu y $\left(a_{y}\right)$

$100 \% \quad 100 \% \quad 100 \%$

$100 \% \quad 100 \% \quad 100 \%$

B. Menemukan persamaan

- Kecepatan arah sumbu $x\left(v_{x}\right)$

- Kecepatan arah sumbu y $\left(v_{y}\right)$

$100 \% \quad 100 \% \quad 100 \%$

$100 \% \quad 100 \% \quad 100 \%$

C. Menemukan persamaan

- Posisi pada sumbu $x$

- Posisi pada sumbu y

D. Menemukan persamaan waktu untuk mencapai titik tertinggi $\left(t_{\text {tertinggi }}\right)$

E. Menemukan persamaan waktu untuk mencapi titik terjauh $\left(t_{\text {maksimum }}\right)$

$100 \% \quad 100 \% \quad 100 \%$

$100 \% \quad 100 \% \quad 100 \%$

$100 \% \quad 100 \% \quad 100 \%$

$100 \% \quad 100 \% \quad 100 \%$

4 Dari simulasi PhET, mahasiswa dapat:

A. Keg. 1.1 menyelidiki dan menyimpulkan apakah massa $(\mathrm{kg})$ mempengaruhi jarak terjauh $\left(x_{j}\right)$, titik tertinggi $\left(y_{t}\right)$ dan waktu jatuh $\left(t_{\text {maksimum }}\right)$ dan waktu untuk mencapai ketinggian maksimum $\left(t_{\text {tertinggi }}\right)$ benda dalam gerak parabola yang dipengaruhi hambatan udara

B. Keg. 1.2 menyelidiki dan menyimpulkan apakah diameter benda mempengaruhi jarak terjauh $\left(x_{j}\right)$, titik tertinggi $\left(y_{t}\right)$ dan waktu jatuh $\left(t_{\text {maksimum }}\right)$ dan waktu untuk mencapai ketinggian maksimum $\left(t_{\text {tertinggi }}\right)$ benda dalam gerak parabola yang dipengaruhi hambatan udara

C. Keg. 1.3 menyelidiki dan menyimpulkan apakah kecepatan awal $\left(v_{0}\right)$ mempengaruhi jarak terjauh $\left(x_{j}\right)$, titik tertinggi $\left(y_{t}\right)$ benda dan waktu jatuh $\left(t_{\text {maksimum }}\right)$ benda dan waktu untuk ketinggian maksimum $\left(t_{\text {tertinggi }}\right)$ pada gerak parabola yang dipengaruhi hambatan udara pada sudut elevasi $(\alpha)$ tertentu.

D. Keg. 1.4 menyelidiki dan menyimpulkan apakah sudut elevasi $(\alpha)$ mempengaruhi jarak terjauh $\left(x_{j}\right)$, titik tertinggi $\left(y_{t}\right)$ benda, waktu jatuh $\left(t_{\text {maksimum }}\right)$ dan waktu untuk mencapai ketinggian maksimum $\left(t_{\text {tertinggi }}\right)$ benda pada gerak parabola yang dipengaruhi hambatan udara.

E. Keg. 1.5 menyelidiki dan menyimpulkan apakah hambatan udara mempengaruhi jarak terjauh $\left(x_{j}\right)$, titik tertinggi $\left(y_{t}\right)$ benda, waktu di titik tertinggi $\left(t_{\text {maksimum }}\right)$, waktu untuk mencapai ketinggian maksimum $\left(t_{\text {tertinggi }}\right)$, dan lintasan gerak parabola pada sudut elevasi tertentu.

5 Mahasiwa mampu menggunakan Microsoft Excel untuk

A. Mengimput data percobaan pada PhET dalam Microsoft Excel

$100 \% \quad 100 \% \quad 100 \%$

$100 \% \quad 100 \% \quad 100 \%$

$100 \% \quad 100 \% \quad 100 \%$

$100 \% \quad 100 \% \quad 100 \%$

$100 \% \quad 100 \% \quad 100 \%$ 


\begin{tabular}{|c|c|c|c|c|}
\hline \multirow{6}{*}{ NO } & \multirow{2}{*}{ Indikator } & \multicolumn{3}{|c|}{ Responden } \\
\hline & & A & B & C \\
\hline & $\begin{array}{l}\text { B. Menghitung waktu untuk mencapai titik tertinggi }\left(t_{\text {tertinggi }}\right) \text { pada gerak } \\
\text { parabola pada bidang datar yang dipengaruhi hambatan udara. }\end{array}$ & $100 \%$ & $100 \%$ & $100 \%$ \\
\hline & $\begin{array}{l}\text { C. Menghitung Ketinggian maksimum ( } y_{\text {maksimum }} \text { ) pada gerak parabola pada } \\
\text { bidang datar yang dipengaruhi hambatan udara. }\end{array}$ & $100 \%$ & $100 \%$ & $100 \%$ \\
\hline & $\begin{array}{l}\text { D. Menghitung waktu untuk mencapai titik terjauh }\left(t_{\text {maksimum }}\right) \text { pada gerak } \\
\text { parabola pada bidang datar yang dipengaruhi hambatan udara. }\end{array}$ & $100 \%$ & $100 \%$ & $100 \%$ \\
\hline & $\begin{array}{l}\text { E. Menghitung jarak maksimum ( } x_{\text {maksimum }} \text { ) pada gerak parabola pada bidang } \\
\text { datar yang dipengaruhi hambatan udara. }\end{array}$ & $100 \%$ & $100 \%$ & $100 \%$ \\
\hline \multirow[t]{3}{*}{6} & Mahasiswa menjawab 70\% pertanyaan-pertanyaan di modul dengan benar & $100 \%$ & $100 \%$ & $100 \%$ \\
\hline & $\begin{array}{ll}\text { Nilai Rata-rata Responden } \\
\end{array}$ & $100 \%$ & $100 \%$ & $100 \%$ \\
\hline & Nilai Observasi & & $100 \%$ & \\
\hline
\end{tabular}

\section{Lembar Kuesioner}

Setelah mahasiswa mengerjakan dan melakukan praktikum secara mandiri, diberikan lembaran kuesioner untuk mengetahui respon dan umpan balik mahasiswa terhadap modul gerak parabola pada bidang datar yang dipengaruhi hambatan udara. Hasil rekapitulasi dari lembaran kuesioner dapat dilihat pada Tabel 2. Berdasarkan tabel rekapitulasi lembaran kuisioner, diperoleh kesimpulan bahwa mahasiswa antusias dalam melakukan praktikum mandiri menggunakan modul gerak parabola pada bidang datar yang dipengaruhi hambatan udara dengan simulasi PhET dan Microsoft Excel. Hal ini terlihat dalam tabel rekapitulasi lembaran kuesioner dimana mahasiswa memberi respon positif terhadap modul praktikum pembelajaran mandiri gerak parabola pada bidang datar yang dipengaruhi hambatan udara memiliki persentase keberhasilan dari modul ini adalah $87 \%$.

Tabel 2 . Lembar Kuesioner

\begin{tabular}{|c|c|c|c|c|c|}
\hline \multirow[t]{2}{*}{ No } & \multirow[t]{2}{*}{ Pertanyaan } & \multicolumn{3}{|c|}{ Responden } & \multirow[t]{2}{*}{ Rata-rata } \\
\hline & & A & $\mathrm{B}$ & C & \\
\hline \multirow[t]{5}{*}{1.} & $\begin{array}{l}\text { Apakah anda mengalami tidak kesulitan (secara matematis) dalam menurunkan } \\
\text { persamaan pada modul gerak parabola yang dipengaruhi hambatan udara pada } \\
\text { persamaan: } \\
\quad \text { - Percepatan }\left(\mathrm{a}_{\mathrm{x}}, \mathrm{a}_{\mathrm{y}}\right)\end{array}$ & 4 & 4 & 4 & $100 \%$ \\
\hline & - $\quad$ Kecepatan $\left(\mathrm{v}_{\mathrm{x}}, \mathrm{v}_{\mathrm{y}}\right)$ & 2 & 3 & 4 & $75,00 \%$ \\
\hline & - $\quad$ Posisi $(\mathrm{x}, \mathrm{y})$ & 3 & 4 & 4 & $91,67 \%$ \\
\hline & - Waktu di titik tertinggi $\left(t_{\text {tertinggi }}\right)$ & 4 & 4 & 3 & $91,67 \%$ \\
\hline & - Waktu terjauh $\left(t_{\text {terjauh }}\right)$ & 2 & 3 & 4 & $75,00 \%$ \\
\hline 2. & $\begin{array}{l}\text { Apakah jenis huruf, ukuran huruf, dan warna gambar dalam modul praktikum } \\
\text { mandiri gerak parabola yang dipengaruhi hambatan udara mudah dibaca? }\end{array}$ & 4 & 4 & 3 & $91,67 \%$ \\
\hline \multirow[t]{2}{*}{3.} & $\begin{array}{l}\text { Apakah modul praktikum mandiri gerak parabola yang dipengaruh hambatan } \\
\text { udara memberikan informasi dan petunjuk pelaksanaan yang jelas tentang apa } \\
\text { yang harus dilakukan pada: }\end{array}$ & 3 & 4 & 3 & $83,33 \%$ \\
\hline & - $\quad$ Simulasi PhET & 3 & 3 & 4 & $83,33 \%$ \\
\hline \multirow[t]{2}{*}{4.} & $\begin{array}{l}\text { Apakah penggunaan kalimat dalam modul gerak pararabola yang dipengaruhi } \\
\text { hambatan udara sederhana dan mudah dipahami? } \\
\text { - Pada penurunan rumus }\end{array}$ & 4 & 4 & 3 & $91,67 \%$ \\
\hline & - $\quad$ Pada simulasi PhET & 4 & 4 & 3 & $91,67 \%$ \\
\hline 5. & $\begin{array}{l}\text { Apakah langkah-langkah dan penjelasan dari modul praktikum mandiri dapat } \\
\text { membuat anda paham mengenai materi gerak parabola yang dipengaruhi } \\
\text { hambatan udara? }\end{array}$ & 3 & 4 & 4 & $91,67 \%$ \\
\hline 6. & $\begin{array}{l}\text { Apakah materi yang dijelaskan dalam modul praktikum mandiri tidak } \\
\text { membosankan? }\end{array}$ & 3 & 3 & 3 & $75,00 \%$ \\
\hline 7. & $\begin{array}{l}\text { Apakah anda tidak mengalami kesulitan menghitung menggunakan Microsoft } \\
\text { Excel? }\end{array}$ & 3 & 3 & 3 & $75,00 \%$ \\
\hline 8. & $\begin{array}{l}\text { Apa anda antusias melakukan praktikum mandiri gerak parabola yang } \\
\text { dipengaruhi hambatan udara menggunakan simulasi PhET "Projectile Motion" } \\
\text { tersebut? }\end{array}$ & 3 & 4 & 3 & $83,33 \%$ \\
\hline
\end{tabular}




\begin{tabular}{|c|c|c|c|c|c|}
\hline \multirow[t]{2}{*}{ No } & \multirow[t]{2}{*}{ Pertanyaan } & \multicolumn{3}{|c|}{ Responden } & \multirow[t]{2}{*}{ Rata-rata } \\
\hline & & $A$ & B & $\mathrm{C}$ & \\
\hline \multirow[t]{2}{*}{9.} & $\begin{array}{l}\text { Apakah belajar dengan media simulasi membantu anda untuk memahami } \\
\text { materi gerak parabola yang dipengaruhi hambatan udara? }\end{array}$ & 4 & 4 & 4 & $100 \%$ \\
\hline & & \multicolumn{3}{|c|}{$\begin{array}{l}\text { Nilai } \\
\text { Kuesioner }\end{array}$} & $87,00 \%$ \\
\hline
\end{tabular}

\section{KESIMPULAN}

Penelitian ini berhasil membuat desain modul praktikum mandiri gerak parabola pada bidang datar yang dipengaruhi hambatan udara menggunakan simulasi PhET "Projectile Motion". Modul ini terdiri dari dua bagian utama yaitu penurunan besaran-besaran fisis gerak parabola secara matematis dan menyelidiki pengaruh dari perubahan besaran-besaran fisis pada gerak parabola menggunakan simulasi PhET "Projectile Motion" dan Microsoft Excel serta menentukan efektifitas dari modul praktikum mandiri gerak parabola pada bidang datar yang dipengaruhi hambatan udara. Berdasarkan lembar observasi, semua sampel dapat mengikuti langkah-langkah dan melakukan praktikum secara mandiri dengan persentase keberhasilan 100 $\%$. Berdasarkan lembar kuesioner, sampel memberikan umpan balik positif $87 \%$ pada penggunaan modul pembelajaran mandiri. Hal ini menujukkan bahwa penggunaan modul pembelajaran mandiri gerak parabola pada bidang datar yang dipengaruhi hambatan udara dapat membantu mahasiswa memahami materi gerak parabola yang dipengaruhi hambatan udara dan melakukan praktikum secara mandiri.

\section{DAFTAR PUSTAKA}

Astuti, N. H., Sudjito, D. N., \& Noviandini, D. (2018). Applying venn diagram to present bloom's cognitive level of students of a physics learning about light refraction using developed independent lab work module and PhET simulation "bending light." Journal of Science \& Science Education, 2(1), 21-28. https://doi.org/10.24246/josse.v2i1p21-28

Boas, M. L. (1976). Mathematical Methods in The Physical Sciences (Third Edition). WILEY.

Dinavalentine, M., Noviandini, D., \& Sudjito, D. N. (2016). Desain Modul Praktikum Mandiri tentang Pembiasan Cahaya Menggunakan Simulasi PhET "Bending Light" untuk Mahasiswa. Prosiding Seminar Nasional Quantum 2016, 91-104.

Halliday, D., Resnick, R., \& Walker, J. (2010). Fisika Dasar (7 ed.). Jakarta: Erlangga.

Henelsmith, N. (2016). Projectile Motion: Finding the Optimal Launch Angle. Whitman College, 1-38.

Karanggulimu, L, Natalia Sudjito, D, \& Noviandini, D. (2017). Desain Modul Praktikum Mandiri Tentang Gerak Parabola Menggunakan Simulasi PhET"Projectile Motion". Seminar Nasional Pendidikan, Sains dan Teknologi Fakultas Matematika dan Ilmu Pengetahuan Alam Universitas Muhammadiyah Semarang, 216-226.

Kartika Sari, B. (2017). Desain Pembelajaran Model Addie Dan Implementasinya Dengan Teknik Jigsaw. Prosiding Seminar Nasional Pendidikan: Tema "Desain Pembelajran Di Era Asean Economic Community (AEC) Untuk Pendidikan Indonesia Berkemajuan" Fakultas Keguruan dan IImu Pendidikan Universitas Muhammadiyah Sidoarjo, 87-102. Diambil dari 3/4/2018.

Maribe Branch, R. (2009). Instructional Design: The ADDIE Approach. Springer New York Dordrecht Heidelberg London, 1-163. https://doi.org/10.1007/978-0-387-09506-6

Morales, D. A. (2005). Exact Expressions For The Range and The Optimal Angle Of A Projectile WWith Linear Drag. 83, 67-83. https://doi.org/10.1139/P04-072

Owen, J. P., \& Ryu, W. S. (2005). The Effects Of Linear and Quadratic Drag On Falling Pheres: An Undergraduate Laboratory. European Journal of Physics, 26, 1085-1091. https://doi.org/10.1088/0143-0807/26/6/016 
Pramitasari, P. (2013). Profil Gerak Peluru Yang Mengalami Rotasi Dengan Hambatan Udara Kuadratik Menggunakan Metode Rungekutta. Universitas Jember Fakutas Matematika dan IImu Pengetahuan Alam, 1-97.

Pujiyono, P., Sudjito, D. N., \& Sudarmi, M. (2016). Desain Pembelajaran Dengan Menggunakan Media Simulasi PHET (Physics Education and Technology) PADA MATERI MEDAN LISTRIK. UPEJ Unnes Physics Education Journal, 5(1). https://doi.org/10.15294/upej.v5i1.12708

Rocca, P. L., \& Riggi, F. (2009). Projectile Motion With A Drag Force: Were The Medievals Right After All? Physics Education, 44(4), 398-402. https://doi.org/10.1088/0031-9120/44/4/009

Symon, K. R. (1971). Mechanics (Third Edition). Addison-Wesley.

Tan, A., \& Edwards, M. E. (2011). The Jerk Vector In Projectile Motion. Lat. Am. J. Phys. Educ., 5(2), 344-347. 